\title{
molecules
}

ISSN 1420-3049

www.mdpi.com/journal/molecules

Communication

\section{Bioactive Oleanane, Lupane and Ursane Triterpene Acid Derivatives}

\author{
Maria de L. e Silva ${ }^{1}$, Juceni P. David ${ }^{1}$, Lidércia C. R. C. Silva ${ }^{1}$, Rauldenis A. F. Santos ${ }^{2}$, \\ Jorge M. David ${ }^{2, *}$, Luciano S. Lima ${ }^{3}$, Pedro S. Reis ${ }^{4}$ and Renato Fontana ${ }^{5}$
}

1 Faculdade de Farmácia, Universidade Federal da Bahia, Rua Barão de Geremoabo, s/n, 41810-290, Salvador, BA, Brazil; E-Mails: lurdinhafarma@yahoo.com.br (M.L.S.); juceni@ufba.br (J.P.D.); liu@ufba.br (L.C.R.C.S.)

2 Instituto de Quimica, Universidade Federal da Bahia, Rua Barão de Geremoabo, s/n, 41810-290, Salvador, BA, Brazil; E-Mail: rauldenis_fonseca@yahoo.com.br

3 Instituto Federal da Bahia, Campus Porto Seguro, Br 367, km 57.5 Fontana I - Porto Seguro, 45810-000, BA, Brazil; E-Mail: lucianolim@yahoo.com.br

4 Núcleo de Pesquisa em Biodiversidade e Biotecnologia - Biotec, Universidade Federal do Piauí, Campus de Parnaíba. 64202-020, Parnaíba, PI, Brazil; E-Mail: reisps@ufpi.edu.br

5 Departamento de Ciências Biológicas, Universidade Estadual de Santa Cruz, Km 16 Rodovia Ilhéus-Itabuna 45662-000, Ilhéus, BA, Brazil; E-Mail: rfontana@uesc.br

* Author to whom correspondence should be addressed; E-Mail: jmdavid@ufba.br; Tel.: +55-71-3283-6864; Fax: +55-71-3235-5166.

Received: 14 September 2012; in revised form: 9 October 2012 / Accepted: 10 October 2012 / Published: 17 October 2012

\begin{abstract}
Betulinic, ursolic and oleanolic acids isolated from the aerial parts of Eriope blanchetii (Lamiaceae) were subjected to different esterification reactions, yielding 12 C-3 position ester derivatives. All compounds were identified using spectroscopic techniques, such as IR, ${ }^{1} \mathrm{H}-\mathrm{NMR}$ and MS. The derivatives were further investigated for their antioxidant level, Artemia salina lethality and antimicrobial activity.
\end{abstract}

Keywords: Eriope blanchetii; Lamiaceae; triterpene derivatives; Artemia salina lethality; antimicrobial activity 


\section{Introduction}

Triterpenes are a class of natural products present in all organisms, especially in plants. The triterpene acids exhibit unique and important biological and pharmacological activities, including anti-inflammatory, antimicrobial, antiviral, cytotoxic and cardiovascular effects [1-5]. Synthesis of triterpene derivatives is a strategy to obtain compounds with enhanced bioactivity by, for example, the introduction of electron-withdrawing/donating groups [6].

Betulinic, ursolic and oleanolic acids are the main triterpenes present in Eriope blanchetii, a shrub belonging to the Lamiaceae family. It is an endemic Brazilian plant and occurs at the sandy soils of the Bahia coast [7]. To date, there are few chemical studies involving this species. Triterpenes and bioactive lignans have been isolated from its organic extracts $[8,9]$.

Previous studies have demonstrated that triterpene acids esterified with cinnamic acid derivatives presented activity against Mycobacterium tuberculosis [10]. The phthalic ester of betulinic acid was shown to be cytotoxic [11], and the dimethylsuccinic ester of betulinic acid was active against human immunodeficiency virus (HIV) [12]. In addition, a number of other ester derivatives of ursolic and oleanolic acids have anti-inflammatory activities [13]. This work describes the synthesis of ester derivatives of betulinic, ursolic and oleanolic acids and the determination of the cytotoxicity of these compounds as determined by their lethality towards Artemia salina (brine shrimp test) and their antimicrobial activity against Escherichia coli (ATCC 25922) and Staphylococcus aureus (ATCC 25923).

\section{Results and Discussion}

Eriope blanchetii is an endemic Brazilian plant that produces considerable amounts of betulinic acid, as well as oleanolic and ursolic acids. These compounds were re-isolated from the aerial parts of this plant using chromatographic techniques. Structural identification of these acids was based on a comparison of their ${ }^{1} \mathrm{H}$ - and ${ }^{13} \mathrm{C}$-NMR spectra with literature spectra for the corresponding methyl ester derivatives [14].

The three triterpene acids were esterified with different anhydrides and/or acyl chlorides. These procedures yielded twelve triterpene acyl derivatives $\mathbf{1 a}-\mathbf{d}, \mathbf{2 a}-\mathbf{d}, \mathbf{3 a}-\mathbf{d}$. The compounds $\mathbf{1 d}, \mathbf{2 d}$ and $\mathbf{3 d}$ are new compounds. The structures of these derivatives were easily confirmed by MS, IR and NMR by comparing their respective data with that of the parent betulinic, oleanolic and ursolic acids. The presence of additional and characteristic $v_{\mathrm{C}=\mathrm{O}}$ and $v_{\mathrm{C}-\mathrm{O}}$ stretches in the IR spectra indicates the presence of an ester functionality. In the ${ }^{1} \mathrm{H}-\mathrm{NMR}$ spectra of these compounds, the esterified products can be identified by the signal of the deshielded H-3 ( $\delta 3.7-4.7)$ compared to the free H-3 $(\delta 3.1-3.4)$ of the triterpene acids (Table 1).

The brine shrimp test was then used to determine the $\mathrm{CL}_{50}$ of each of the prepared compounds. Compounds with a $\mathrm{CL}_{50}$ greater than $1,000 \mu \mathrm{g} / \mathrm{mL}$ can be considered inactive, those with a $\mathrm{CL}_{50}$ less than $100 \mu \mathrm{g} / \mathrm{mL}$ are very active, and those with a $\mathrm{CL}_{50}$ between 100 and $900 \mu \mathrm{g} / \mathrm{mL}$ are considered moderate [15]. Table 2 shows the results observed for the derivatives. Most of the prepared compounds are inactive, but 3 $\beta$-(3-chlorobenzoyl) betulinic acid (1d) showed a remarkable activity $\left(\mathrm{CL}_{50}=117.1 \mu \mathrm{g} / \mathrm{mL}\right)$. Betulinic acid is known for its antitumor activities, so this observation can explain the higher activity of $\mathbf{1 d}$ compared to $\mathbf{2 d}$ and $\mathbf{3 d}$. 
Table 1. H-3 ${ }^{1} \mathrm{H}-\mathrm{NMR}$ data for betulinic, oleanolic and ursolic acids and their ester derivatives [300 MHz, $\delta(\mathrm{ppm}) J(\mathrm{~Hz})]$.

\begin{tabular}{ccc}
\hline Compound & Solvent & $\boldsymbol{\delta} \mathbf{H - 3}$ \\
\hline $\mathbf{1}$ & $\mathrm{Py}$ & $3.5(t, 7.0 \mathrm{~Hz})$ \\
$\mathbf{1 a}$ & $\mathrm{Cd}$ & $4.48(t, 7.7 \mathrm{~Hz})$ \\
$\mathbf{1 b}$ & $\mathrm{Cd}$ & $4.48(t, 7.7 \mathrm{~Hz})$ \\
$\mathbf{1 c}$ & $\mathrm{Ac}$ & $3.9(t, 7.7 \mathrm{~Hz})$ \\
$\mathbf{1 d}$ & $\mathrm{Ac}$ & $3.7(t, 7.1 \mathrm{~Hz})$ \\
$\mathbf{2}$ & $\mathrm{Py}$ & $3.5(t, 8.0 \mathrm{~Hz})$ \\
$\mathbf{2 a}$ & $\mathrm{Cd}$ & $4.51(t, 7.7 \mathrm{~Hz})$ \\
$\mathbf{2 b}$ & $\mathrm{Ac}$ & $4.49(m, 7.7 \mathrm{~Hz})$ \\
$\mathbf{2 c}$ & $\mathrm{Ac}$ & $4.7(t, 7.7 \mathrm{~Hz})$ \\
$\mathbf{2 d}$ & $\mathrm{Ac}$ & $4.35(t, 7.7 \mathrm{~Hz})$ \\
$\mathbf{3}$ & $\mathrm{Py}$ & $3.48(t, 7.8 \mathrm{~Hz})$ \\
3a & $\mathrm{Cd}$ & $4.51(d d, 6.0 \mathrm{and} 8.6 \mathrm{~Hz})$ \\
3b & $\mathrm{Cd}$ & $4.51(d d, 5.6 \mathrm{e} 8.9 \mathrm{~Hz})$ \\
3c & $\mathrm{Cd}$ & $4.76(d d, 5.6 \mathrm{e} 8.9 \mathrm{~Hz})$ \\
3d & $\mathrm{Cd}$ & $4.75(t, 8.9 \mathrm{~Hz})$ \\
\hline Py $=$ pyridine- $d_{5}, \mathrm{Ac}=$ acetone- $d_{6}, \mathrm{Cd}=\mathrm{CDCl}{ }_{3}$.
\end{tabular}

Table 2. Cytotoxicity evaluation by the brine shrimp test of triterpene acid derivatives.

\begin{tabular}{ccc}
\hline Compound & \multicolumn{2}{c}{ Lethality towards Artemia salina } \\
\hline & $\mathrm{CL}_{50}(\mu \mathrm{g} / \mathrm{mL})$ & $\mathrm{SD}$ \\
$\mathbf{1 a}$ & $>1,000 \mu \mathrm{g} / \mathrm{mL}$ & - \\
$\mathbf{1 b}$ & $>1,000 \mu \mathrm{g} / \mathrm{mL}$ & - \\
$\mathbf{1 c}$ & $>1000 \mu \mathrm{g} / \mathrm{mL}$ & - \\
$\mathbf{1 d}$ & $117.1 \mu \mathrm{g} / \mathrm{mL}$ & 0.418 \\
2a & $>1,000 \mu \mathrm{g} / \mathrm{mL}$ & \\
2b & $>1,000 \mu \mathrm{g} / \mathrm{mL}$ & - \\
2c & $>1,000 \mu \mathrm{g} / \mathrm{mL}$ & - \\
2d & $477.2 \mu \mathrm{g} / \mathrm{mL}$ & 0.304 \\
3a & $>1,000 \mu \mathrm{g} / \mathrm{mL}$ & - \\
3b & $>1,000 \mu \mathrm{g} / \mathrm{mL}$ & - \\
3c & $>1,000 \mu \mathrm{g} / \mathrm{mL}$ & - \\
3d & $>1,000 \mu \mathrm{g} / \mathrm{mL}$ & - \\
\hline SD with $95 \%$ confidence interval $(\mu \mathrm{g} / \mathrm{mL})$.
\end{tabular}

Aliphatic compounds with no conjugated double bonds usually do not show considerable antioxidant activities [16], but triterpenes esterified with cinnamic acid derivatives have been known to exhibit scavenging activity when employing the DPPH reagent [17]. All of our derivatives were subjected to this test, and as expected, the majority of the compounds were unable to quench the free radical (Table 3), but 3 $\beta$-(3-chlorobenzoyl) betulinic acid (1d) had an $\mathrm{IC}_{50}$ similar to quercetin, the positive control employed. Betulinic, ursolic and oleanolic acids are also known to possess antimicrobial activities. The derivatives were inactive at 80 and $240 \mu \mathrm{g}$ doses when tested against 
E. coli and S. aureus. Therefore, the presence of a free hydroxyl group at C-3 appears to be important for activity.

Table 3. Scavenging activity observed for $\mathbf{1 d}, \mathbf{2} \mathbf{a}$ and $\mathbf{2 d}$ in the DPPH test.

\begin{tabular}{cc}
\hline Compound & IC $_{\mathbf{5 0}} \pm \mathbf{R S D}(\boldsymbol{\mu \mathbf { g }} / \mathbf{m L})$ \\
\hline $\mathbf{2 d}$ & $1444 \pm 2.0$ \\
1d & $23.41 \pm 0.9$ \\
2a & $44.58 \pm 0.7$ \\
Quercetin (positive control) & $23.18 \pm 1.4$ \\
\hline
\end{tabular}

\section{Experimental}

\subsection{General Procedures}

${ }^{1} \mathrm{H}-\mathrm{NMR}(300 \mathrm{MHz}$ ) experiments were carried out on a Varian Gemini 2000 or a Bruker AMX300; chemical shifts were recorded in $\delta(\mathrm{ppm})$ from the solvent peak relative to TMS. APCI and ESI-MS data were obtained on a Shimadzu LCMS-2010, and IR spectra were recorded on a Varian 640-IR spectrophotometer. Column chromatography was carried using silica gel 60 (Akros 0.04-0.073 mm), and silica gel TLC plates employing iodine fumes, the Libermann-Burchard spray reagent, and UV light $(254 / 366 \mathrm{~nm})$ were used to monitor chromatographic purification.

\subsection{Plant Material}

Botanical material of Eriope blanchetii (Lamiaceae) was collected in May 2008 at Parque Metropolitano do Abaeté, Salvador, Bahia State, a region where "restinga" vegetation is prevalent. The species was identified by Prof. Maria L. S. Guedes, and a voucher is deposited at Herbário Prof. Alexandre Leal Costa, Instituto de Biologia da UFBA, under number 045599.

\subsection{Extraction and Isolation}

The dried and powdered aerial parts of E. blanchetii $(1.7 \mathrm{~kg})$ were repeatedly extracted with $\mathrm{MeOH}$ $(4 \mathrm{~L}, 48 \mathrm{~h})$ at room temperature, and the crude extract was immediately partitioned. Firstly it was solubilized with $\mathrm{MeOH}-\mathrm{H}_{2} \mathrm{O}(9: 1)$ and extracted by hexane and sequentially the hydroalcoholic portion was solubilized with $\mathrm{MeOH}-\mathrm{H}_{2} \mathrm{O}$ (6:4) and then partitioned employing $\mathrm{CHCl}_{3}$. After the evaporation of the $\mathrm{CHCl}_{3}$ under vacuum, the extract obtained (47.2 g) was loaded onto the silica gel column and eluted with a $\mathrm{CHCl}_{3}: \mathrm{MeOH}$ gradient $(95: 5 \rightarrow 3: 2)$. The fractions rich in triterpenes were identified by TLC using the Liebermann-Burchard spray reagent. These fractions were then loaded onto a Sephadex $\mathrm{LH}-20$ column and eluted with $\mathrm{CHCl}_{3}-\mathrm{MeOH}(2: 3)$; the eluate was then loaded onto a silica gel column and eluted with mixtures of hexane/EtOAc. These procedures yielded pure betulinic (2.5 g), oleanolic (903 $\mathrm{mg}$ ) and ursolic (570 $\mathrm{mg}$ ) acids. 


\subsection{Synthesis of the Ester Derivatives}

Ester derivatives of the triterpene acids were synthesized via reaction with anhydrides. The triterpene acids (20 mg), pyridine (2 mL) and 2,4-dimethylaminepiridine (DMAP, $2.0 \mathrm{mg}$ ) were placed in a $50 \mathrm{~mL}$ flask. Sequentially, propionic or butyric anhydride $(0.4 \mathrm{~mL})$ or benzoic anhydride $(10 \mathrm{mg})$ were added to each flask. The mixtures were stirred for $24 \mathrm{~h}$ at $45{ }^{\circ} \mathrm{C}$. The solvent was removed. The products were then dissolved in $\mathrm{CHCl}_{3}$ and treated with $\mathrm{H}_{2} \mathrm{O}$, dried with $\mathrm{Na}_{2} \mathrm{SO}_{4}$, filtered and the solvent removed twice under vacuum. The products were purified by silica gel column chromatography, with hexane-EtOAc (9:1) as the eluent. Table 4 gives the yields from this procedure for the triterpene acid esters (Schemes 1 and 2).

Table 4. Yields * of purified ester triterpene acid derivatives.

\begin{tabular}{ccc}
\hline Triterpene acid derivatives & m (mg) & Yield (\%) \\
\hline 1a & 1.7 & 10 \\
1b & 1.7 & 10 \\
1c & 13.5 & 56 \\
1d & 8.1 & 33 \\
2a & 1.4 & 9 \\
2b & 1.3 & 7 \\
2c & 8.1 & 33 \\
2d & 17.1 & 66 \\
3a & 12.7 & 55 \\
3b & 13.8 & 60 \\
3c & 7.3 & 37 \\
3d & 19.1 & 69 \\
\hline
\end{tabular}

* The yields are expressed as purified compound. In some of the reactions the subproducts obtained from the anhydrides and acid chlorides presented similar $\mathrm{Rf}$ in chromatography and the ester purification was not complete.

Scheme 1. Preparation of the ester derivatives from betulinic acid.

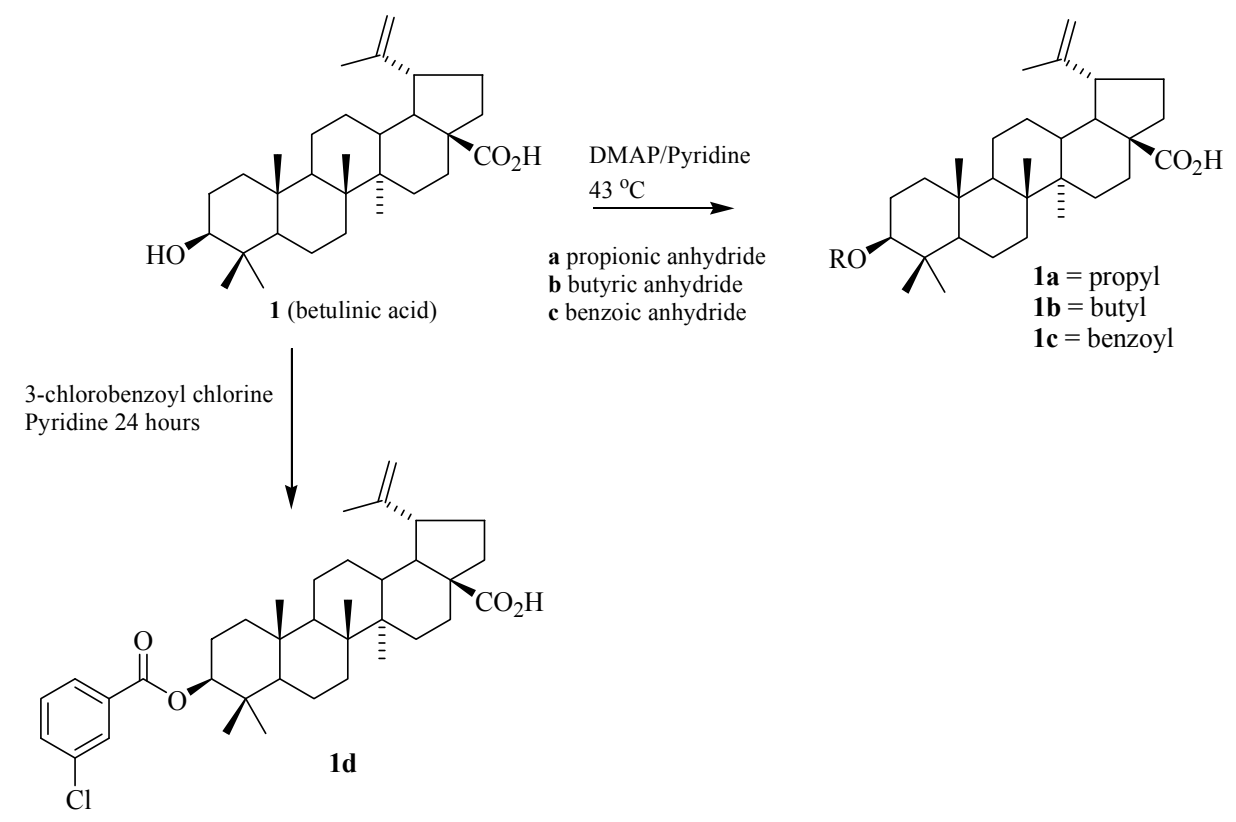


Scheme 2. Preparation of the ester derivatives from oleanolic and ursolic acids.
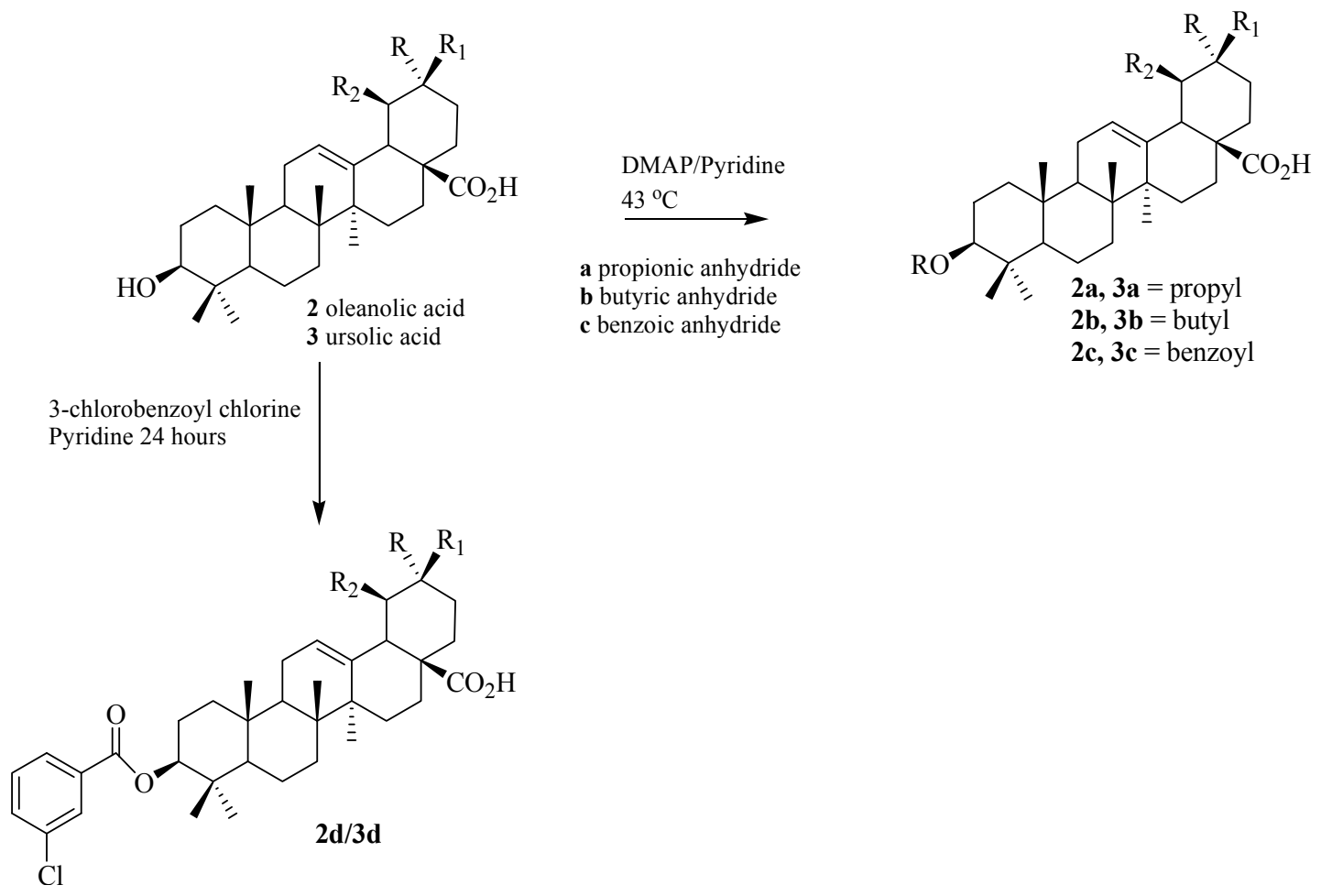

Ester derivatives of the triterpene acids were also prepared with 3-chlorobenzoyl chloride. The three triterpene acids $(20 \mathrm{mg})$ and pyridine $(2 \mathrm{~mL})$ were separately placed in a $50 \mathrm{~mL}$ flask. Next 3 -chlorobenzoyl chloride $(23 \mu \mathrm{L})$ was added, and the mixtures were stirred in an ice bath for $24 \mathrm{~h}$. The solvent was then removed, and the products were purified by silica gel column chromatography, with hexane-EtOAc (8:2) as the eluent. Table 4 gives the yields from this procedure for the esters of the triterpene acids (Schemes 1 and 2).

3ß-Propanoyl betulinic acid (1a) APCI-MS $m / z 511[\mathrm{M}-\mathrm{H}] ;{ }^{1} \mathrm{H}-\mathrm{NMR}\left(\mathrm{CDCl}_{3}\right), \delta$ ppm: 5.1 and 5.0 (1H, s, H-29); 4.48 (1H, $J=7.7 \mathrm{~Hz}, \mathrm{t}, \mathrm{H}-3) ; 2,02$ (1H, $J=11 \mathrm{~Hz}, \mathrm{~d}, \mathrm{H}-18)$.

3ß-Butanoyl betulinic acid (1b) APCI-MS m/z $525[\mathrm{M}-\mathrm{H}] ;{ }^{1} \mathrm{H}-\mathrm{NMR}\left(\mathrm{CDCl}_{3}\right), \delta$ ppm: 5.1 and 5.0 (2H, s, H-29); 4,48 (1H, $J=7.7 \mathrm{~Hz}, \mathrm{t}, \mathrm{H}-3) ; 2.02$ (1H, $J=11 \mathrm{~Hz}, \mathrm{~d}, \mathrm{H}-18)$.

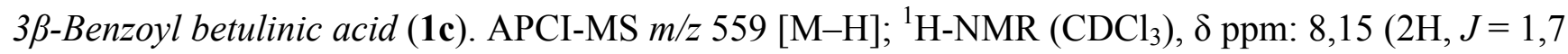
and $\left.8.3 \mathrm{~Hz}, \mathrm{dt}, \mathrm{H}-3^{\prime}, 7^{\prime}\right) ; 7,65\left(1 \mathrm{H}, J=1.3\right.$ and $\left.7.5 \mathrm{~Hz}, \mathrm{tt}, \mathrm{H}-5^{\prime}\right) ; 7.5\left(2 \mathrm{H}, J=1.5\right.$ and $8 \mathrm{~Hz}, \mathrm{td}, \mathrm{H}-4^{\prime}$ and 6'); 4.62 and 4.72 (1H, s, H-29); $3.9(1 \mathrm{H}, J=7.7 \mathrm{~Hz}, \mathrm{t}, \mathrm{H}-3) ; 2.07(1 \mathrm{H}, J=11 \mathrm{~Hz}, \mathrm{~d}, \mathrm{H}-18)$.

33-3-Chlorobenzoyl betulinic acid (1d). White power. M.p. 165.9-166.4 ${ }^{\circ} \mathrm{C}$. APCI-MS $\mathrm{m} / \mathrm{z} 593$ [M-H]; IR $\left(\mathrm{KBr}, \mathrm{cm}^{-1}\right)$ : 3522-3281 ( $\left.\mathrm{v}_{\mathrm{OH}}\right), 2925-2852\left(\mathrm{v}_{\mathrm{C}-\mathrm{H}}\right), 1689\left(\mathrm{v}_{\mathrm{C}=\mathrm{O}}\right), 1684\left(\mathrm{v}_{\mathrm{C}=\mathrm{O}}\right), 1575\left(\mathrm{v}_{\mathrm{C}=\mathrm{C}}\right)$,

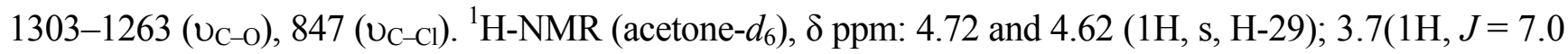
$\mathrm{Hz}, \mathrm{t}, \mathrm{H}-3) ; 2.04$ (1H, $J=11.0 \mathrm{~Hz}, \mathrm{~d}, \mathrm{H}-18)$.

3ß-Propanoyl oleanolic acid (2a): APCI-MS m/z 511 [M-H]; ${ }^{1} \mathrm{H}-\mathrm{NMR}\left(\mathrm{CDCl}_{3}\right), \delta: 5,25(1 \mathrm{H}, \mathrm{s}, \mathrm{H}-12)$; $\left.4.51(1 \mathrm{H}, J=7.7 \mathrm{~Hz}, \mathrm{t}, \mathrm{H}-3) ; 2.34(2 \mathrm{H}, J=7.5 \mathrm{~Hz}, \mathrm{q}, \mathrm{H}-2)^{\prime}\right) ; 2.2(1 \mathrm{H}, J=11.0 \mathrm{~Hz}, \mathrm{~d}, \mathrm{H}-18)$. 
3ß-Butanoyl oleanolic acid (2b): APCI-MS m/z $525[\mathrm{M}-\mathrm{H}] ;{ }^{1} \mathrm{H}-\mathrm{NMR}\left(300 \mathrm{MHz}\right.$, acetone- $\left.d_{6}\right), \delta$ ppm: 4.49 (1H, $J=7,7 \mathrm{~Hz}, \mathrm{~m}, \mathrm{H}-3)$.

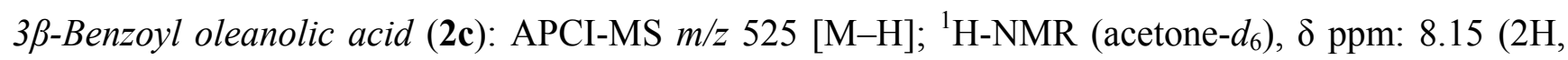
$J=1.7$ and $\left.8.3 \mathrm{~Hz}, \mathrm{dt}, \mathrm{H}-3^{\prime}, 7^{\prime}\right) ; 7.65\left(1 \mathrm{H}, J=1.3\right.$ and $\left.7.5 \mathrm{~Hz}, \mathrm{tt}, \mathrm{H}-5^{\prime}\right) ; 7.5(2 \mathrm{H}, J=1.5 \mathrm{and} 8.0 \mathrm{~Hz}$, td, H-4' e 6'); 5.23 (1H, s, H-12); 4.7 (1H, $J=7.7 \mathrm{~Hz}, \mathrm{t}, \mathrm{H}-3)$.

33-3-Chlorobenzoyl oleanolic acid (2d): White power. M.p. 152.9-154.1 ${ }^{\circ} \mathrm{C}$ APCI-MS $\mathrm{m} / \mathrm{z} 593$ [M-H];

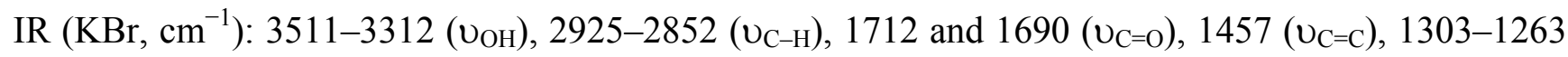
$\left(\mathrm{v}_{\mathrm{C}-\mathrm{O}}\right), 894\left(\mathrm{v}_{\mathrm{C}-\mathrm{Cl}}\right) .{ }^{1} \mathrm{H}-\mathrm{NMR}$ (acetone- $\left.d_{6}\right), \delta \mathrm{ppm}$ : $7.99\left(1 \mathrm{H}, \mathrm{s}, \mathrm{H}-3{ }^{\prime}\right) ; 7.99-7.96\left(1 \mathrm{H}, \mathrm{m}, \mathrm{H}-7^{\prime}\right) ; 7.6(1 \mathrm{H}$, d, H-5'); 7.5 (1H, t, H-6'); 4.35 (1H, J= $7.7 \mathrm{~Hz}, \mathrm{t}, \mathrm{H}-3) ; 2.3$ (1H, J=11 Hz, d, H-18).

33-Propanoyl ursolic acid (3a): White power. M.p. $266.5-267.3{ }^{\circ} \mathrm{C}$. IR $\left(\mathrm{KBr}, \mathrm{cm}^{-1}\right)$ : 3006-2879 $\left(\mathrm{U}_{\mathrm{C}-\mathrm{H}}\right)$, 1734 and $1712\left(\mathrm{v}_{\mathrm{C}=\mathrm{O}}\right), 1222\left(\mathrm{U}_{\mathrm{C}-\mathrm{O}}\right) .{ }^{1} \mathrm{H}-\mathrm{NMR}\left(\mathrm{CDCl}_{3}\right), \delta \mathrm{ppm}: 5.2(1 \mathrm{H}, J=3.3 \mathrm{~Hz}, \mathrm{t}, \mathrm{H}-12) ; 4.51(1 \mathrm{H}$, $J=6.0$ and $8.6 \mathrm{~Hz}, \mathrm{dd}, \mathrm{H}-3) ; 2.3-2.4\left(2 \mathrm{H}, J=7.5 \mathrm{~Hz}, \mathrm{q}, \mathrm{H}-2^{\prime}\right) ; 2.2(1 \mathrm{H}, J=11 \mathrm{~Hz}, \mathrm{~d}, \mathrm{H}-18)$.

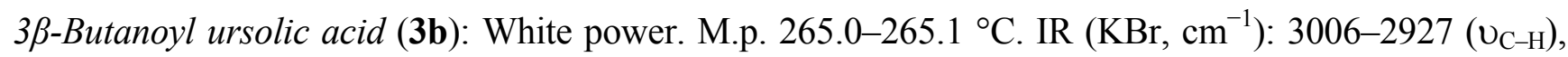
1734 and $1714\left(\mathrm{v}_{\mathrm{C}=\mathrm{O}}\right), 1222\left(\mathrm{v}_{\mathrm{C}-\mathrm{O}}\right) .{ }^{1} \mathrm{H}-\mathrm{NMR}\left(\mathrm{CDCl}_{3}\right), \delta \mathrm{ppm}: 5.2(1 \mathrm{H}, J=3.3 \mathrm{~Hz}, \mathrm{t}, \mathrm{H}-12) ; 4.51(1 \mathrm{H}$, $J=5.6$ and $8.9 \mathrm{~Hz}, \mathrm{dd}, \mathrm{H}-3) ; 2.3-2.4(2 \mathrm{H}, J=7.2 \mathrm{~Hz}, \mathrm{t}, \mathrm{H}-2 ') ; 2.2(1 \mathrm{H}, J=11 \mathrm{~Hz}, \mathrm{~d}, \mathrm{H}-18)$.

3ß-Benzoyl ursolic acid (3c): White power. M.p. 197.3-199.5 ${ }^{\circ} \mathrm{C}$. IR (film, $\left.\mathrm{cm}^{-1}\right)$ : 3006-2926 $\left(\mathrm{v}_{\mathrm{C}-\mathrm{H}}\right)$, $1714\left(\mathrm{v}_{\mathrm{C}=\mathrm{O}}\right), 1222\left(\mathrm{v}_{\mathrm{C}-\mathrm{O}}\right) .{ }^{1} \mathrm{H}-\mathrm{NMR}\left(\mathrm{CDCl}_{3}\right), \delta \mathrm{ppm}: 8.15\left(2 \mathrm{H}, J=1.7\right.$ and $8.3 \mathrm{~Hz}, \mathrm{dt}, \mathrm{H}-3$ ', $\left.7^{\prime}\right) ; 7.65$ $\left(1 \mathrm{H}, J=1.3\right.$ and $\left.7.5 \mathrm{~Hz}, \mathrm{tt}, \mathrm{H}-5^{\prime}\right) ; 7.5\left(2 \mathrm{H}, J=1.5\right.$ and $8.0 \mathrm{~Hz}, \mathrm{td}, \mathrm{H}-4^{\prime}$ and $\left.6^{\prime}\right) ; 5.3(1 \mathrm{H}, \mathrm{s}, \mathrm{H}-12) ; 4.76$ $(1 \mathrm{H}, J=5.6$ and $8.9 \mathrm{~Hz}, \mathrm{dd}, \mathrm{H}-3) ; 2.25(1 \mathrm{H}, J=11 \mathrm{~Hz}, \mathrm{~d}, \mathrm{H}-18)$.

33-3-Chlorobenzoyl ursolic acid (3d): White power. M.p. $155.2-157.9^{\circ} \mathrm{C}$. IR $\left(\mathrm{KBr}, \mathrm{cm}^{-1}\right)$ : 3084-2867 $\left(v_{\mathrm{OH}}\right), 3005-2925\left(v_{\mathrm{C}-\mathrm{H}}\right), 1721\left(\mathrm{v}_{\mathrm{C}=\mathrm{O}}\right), 1693\left(\mathrm{v}_{\mathrm{C}=\mathrm{O}}\right), 1572\left(\mathrm{v}_{\mathrm{C}=\mathrm{C}}\right), 1291-1256\left(\mathrm{v}_{\mathrm{C}-\mathrm{O}}\right), 846\left(\mathrm{v}_{\mathrm{C}-\mathrm{Cl}}\right)$. ${ }^{1} \mathrm{H}-\mathrm{NMR}\left(\mathrm{CDCl}_{3}\right), 8.1\left(1 \mathrm{H}, J=1.7\right.$ and $\left.\left.2.5 \mathrm{~Hz}, \mathrm{dd}, \mathrm{H}-3^{\prime}\right) ; 8.0(1 \mathrm{H}, J=1.0 \text { and } 7.5 \mathrm{~Hz}, \mathrm{dt}, \mathrm{H}-7)^{\prime}\right) ; 7.5(1 \mathrm{H}, J$ $=1.0$ and $\left.8.0 \mathrm{~Hz}, \mathrm{td}, \mathrm{H}^{-} 5^{\prime}\right) ; 7.4\left(1 \mathrm{H}, J=7.8 \mathrm{~Hz}, \mathrm{t}, \mathrm{H}-6^{\prime}\right) ; 5.2(1 \mathrm{H}, J=3.3 \mathrm{~Hz}, \mathrm{t}, \mathrm{H}-12) ; 4.75(1 \mathrm{H}, J=8.9$ $\mathrm{Hz}, \mathrm{t}, \mathrm{H}-3) ; 2.2(1 \mathrm{H}, J=11 \mathrm{~Hz}, \mathrm{~d}, \mathrm{H}-18)$.

\subsection{Biological Tests}

The brine shrimp lethality test was performed according to Serrano et al. [18] with minor modifications [8]. Radical scavenging activities of plant extracts were determined through spectrophotometry using the 1,1-diphenyl-2-picrylhydrazyl (DPPH) scavenging radical assay [19]. The radical scavenging ability was calculated by the formula, $\% \mathrm{I}=[(\mathrm{AbsB}-\mathrm{Abs} \mathrm{A}) / \mathrm{AbsB}] \times 100$, and the $\mathrm{IC}_{50}$ was determined from the linear decrease in the inhibition percentage.

All assays were performed in triplicate, and the test results were analyzed using the two-tailed Student's t-test at a significance level of $p<0.05$. DPPH $\mathrm{IC}_{50}$ values with $95 \%$ confidence intervals were determined using the regression method with the Analyse-it software. BST LC L $_{50}$ values with 95\% confidence intervals were determined using the probit analysis method of the Stats Direct statistical software. When required, the results were found by extrapolation of the straight line. 
The antimicrobial activity tests on the oils were performed using the method of diffusion in agar previously described in [20]. The oils were tested against gram-positive and gram-negative species, Staphylococcus aureus (ATCC 25923) and Escherichia coli (ATCC 25922), respectively. A suspension of the tested microorganism (0.5 of MacFarland Scale) was spread onto Petri plates with Mueller Hinton agar (Difco Laboratories, Detroit, MI, USA). Then, 240 and $80 \mu \mathrm{g}$ of the triterpenes were added to a $2 \mathrm{~mm}$ diameter area of the paper dishes. The plates were incubated at $37{ }^{\circ} \mathrm{C}$ for $24 \mathrm{~h}$. After this period of time, the diameters of the inhibition zones were measured using a caliper rule and expressed in millimeters.

\section{Conclusions}

The esterification reactions of betulinic, oleanolic and ursolic acids led to preparation of several triterpene $\mathrm{C}-3$ position derivatives. Among these compounds 3 $\beta$-3-chlorobenzoyl betulinic acid (1d),

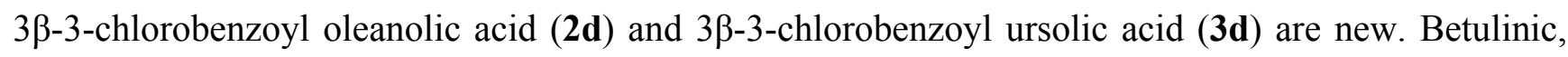
ursolic and oleanolic acids are also known to possess antimicrobial activities but the derivatives were inactive when tested against $E$. coli and $S$. aureus, indicating that the presence of a free hydroxyl group at C-3 appears to be important for activity. Nevertheless compound $\mathbf{1 d}$ showed activity in the Brine Shrimp Test and exhibited scavenging activity when employing the DPPH reagent.

\section{Acknowledgments}

The authors are grateful to the Conselho Nacional de Desenvolvimento Científico e Tecnológico CNPq (Brazil), PRONEM and PRONEX (FAPESB/CNPq), and the Fundação Coordenação de Aperfeiçoamento de Pessoal de Nível Superior (CAPES) for fellowship support and grants.

\section{References}

1. Connolly, J.; Hill, R. Triterpenoids. Nat. Prod. Rep. 2008, 25, 794-830.

2. Huang, M.-T.; Ho, C.-H.; Wang, Z.Y.; Ferraro, T.; Lou, Y.-R.; Stauber, K.; Ma, W.; Georgiadis, C.; Laskin, J.D.; Conney, A.H. Inhibition of Skin Tumorigenesis by Rosemary and Its Constituents Carnosol and Ursolic Acid. Cancer Res. 1994, 54, 701-708.

3. Vechia, L.D.; Gnoatto, S.C.B.; Gosmann, G. Oleanane and ursane derivatives and their importance on the discovery of potential antitumour, antiinflammatory and antioxidant drugs. Quim. Nova 2009, 32, 1245-1252.

4. Maia, J.L.; Lima-Junior, R.C.P.; David, J.P.; David, J.M.; Santos, F.A.; Rao, V.S. Oleanolic Acid, a Pentacyclic Triterpene Attenuates the Mustard Oil-Induced Colonic Nociception in Mice. Biol. Pharm. Bull. 2006, 29, 82-85.

5. Maia, J.L.; Lima-Junior, R.C.P.; Melo, C.M.; David, J.P.; David, J.M.; Campos, A.R.; Santos, F.A.; Rao, V.S. Oleanolic acid, a pentacyclic triterpene attenuates capsaicin-induced nociception in mice: Possible mechanisms. Pharmacol. Res. 2006, 54, 282-286.

6. Cechinel-Filho, V.; Yunes, R.A. Estrategies for obtaining pharmacologically active compounds from medicinal plants. Concepts about structural modification for improve the activity. Quim. Nova 1998, 21, 99-105. 
7. Harley, R.M. A review of Eriope and Eriopdion (Labiatae). Hooker's Icon. Pl. 1976, 38, 1-107.

8. David, J.P.; da Silva, E.F.; de Moura, D.L.; Guedes, M.L.S.; Assunção, R.J.; David, J.M. Lignans and triterpenes from cytotoxic extract of Eriope blanchetii. Quim. Nova 2001, 24, 730-733.

9. Santos, E.O.; Lima, L.S.; David, J.M.; Martins, L.C.; Guedes, M.L.S.; David, J.P. Podophyllotoxin and other aryltetralin lignans from Eriope latifolia and Eriope blanchetii. Nat. Prod. Res. 2011, $25,1450-1453$.

10. Tanachatchairatana, T.; Bremner, J.B.; Chokchaisiri, R.; Suksamrarn, A. Antimycobacterial activity of cinnamate-based esters of the triterpenes betulinic, oleanolic and ursolic acids. Chem. Pharm. Bull. 2008, 56, 194-198.

11. Kvasnica, M.; Sarek, J.; Klinotova, E.; Dzubakb, P.; Hajduchb, M. Synthesis of phthalates of betulinic acid and betulin with cytotoxic activity. Bioorg. Med. Chem. 2005, 13, 3447-3454.

12. Qian, K.; Nakagawa-Gotoa, K.; Yu, D.; Marris-Natschkea, S.L.; Nitz, T.J.; Kilgore, N.; Allaway, G.P.; Lee, K.-H. Anti-AIDS Agents 73: Structure-Activity Relationship Study and Asymmetric Synthesis of 3-O-Monomethylsuccinyl Betulinic Acid Derivatives. Bioorg. Med. Chem. Lett. 2007, 17, 6553-6557.

13. Honda, T.; Finlay, H.J.; Gribble, G.W.; Suh, N.; Sporn, M.B. New enone derivatives of oleanolic acid and ursolic acid as inhibitors of nitric oxide production in mouse macrophages. Bioorg. Med. Chem. Lett. 1997, 7, 1623-1628.

14. Mahato, S.B.; Kundu, A.P. ${ }^{13}$ C-NMR Spectra of Pentacyclic Triterpenoids-A compilation and some salient features. Phytochemistry 1994, 37, 1517-1575.

15. Anderson, J.E.; Goetz, A. A blind comparison of simple bench-top bioassays and human tumour cell cytotoxicities as antitumor prescreens. Phytochem. Anal. 1991, 2, 107-111.

16. Barreiros, A.L.B.S.; David, J.M.; David, J.P. Oxidative stress: Relations between the formation of reactive species and the organism's defense. Quim. Nova 2006, 29, 113-123.

17. Barreiros, A.L.B.S.; David, J.M.; David, J.P. Antioxidant Phenylpropanoid Esters of Triterpenes from Dioclea lasiophylla. Pharm. Biol. 2004, 42, 36-38.

18. Serrano, C.; Ortega, T.; Villar, A. Biological activity of traditional medicines from Spain and Guatemala. Artemia salina Bioassays: A revision. Phytother. Res. 1996, 10, S118-S120.

19. Aguiar, R.M.; Alves, C.Q.; David, J.M.; e Luciano S. Lima, L.C.R.; David, J.P.; de Queiróz, L.P. Antioxidant activities of isolated compounds from stems of Mimosa invisa Mart. ex Colla. Quim. Nova 2012, 35, 567-570.

20. Fontana, R.; Mendes, M.A.; Souza, B.M.; Donno, K.; César, L.M.M.; Palma, M.S. Jelleines: A family of antimicrobial peptides from the royal jelly of honeybees (Apis mellifera). Peptides 2004, 27, 2624-2631.

Sample Availability: Samples of the compounds 1, 2, 3, 1a-d, 2a-d and 3a-d are available from the authors.

(C) 2012 by the authors; licensee MDPI, Basel, Switzerland. This article is an open access article distributed under the terms and conditions of the Creative Commons Attribution license (http://creativecommons.org/licenses/by/3.0/). 